\title{
MENGEMBANGKAN KARAKTER TANGGUNG JAWAB DAN KEMAMPUAN AKADEMIK SISWA MELALUI PENDEKATAN PEMBELAJARAN PENEMUAN (DISCOVERY LEARNING)
}

\author{
Khaeruddin ${ }^{1)}$ \\ Muslimin Ibrahim ${ }^{2)}$ \\ Z.A. Imam Supardi ${ }^{2}$ \\ ${ }^{1)}$ Guru Fisika SMK Negeri 2 Sumbawa Besar \\ ${ }^{2)}$ Dosen Pascasarjana Prodi Pendidikan Sains Universitas Negeri Surabaya
}

\begin{abstract}
This study investigated the difference of student's cognitive competency, scientific skills, and responsibility level after following teaching and learning process using discovery learning type less structured guided discovery and type guided discovery and describes the implementation and student's activity on physics learning using teaching material based on discovery learning approah. The Subject of this study was students $10^{\text {th }}$ grade of SMK Negeri 2 Sumbawa Besar at $2^{\text {nd }}$ semester academic year 2010/2011. It was experimental research of two-groups pretesst-posttest design. The techniques of data collecting are testing and observing. The data were analyzed desciptively and by using inferential statistic. The results revealed that: (1) Student's cognitive competency, scientific skills, and responsibility level after following teaching and learning process using discovery approach with less structured guided discovery type was better than guided discovery type (2) The implemnetation of physic learning by using teaching material which based on discovery learning on both less structured guided discovery and guided discovery types were each 98.08\%; (3) The steps of discovery learning on both less structured guided discovery and guided discovery types have been proved to be able develope student's academic competency and responsibility character; (4) Student's activities at physics learning by using teaching material which based on discovery learning described activities which relevant with steps of discovery learning on both the less structured guided discovery and guided discovery types.
\end{abstract}

Keywords: responsibility character, academic competency, discovery learning approach.

\begin{abstract}
Abstrak: Penelitian ini bertujuan untuk menguji adanya perbedaan kemampuan kognitif, keterampilan ilmiah, dan tingkat tanggung jawab siswa setelah diberikan pembelajaran discovery dengan tipe berbeda dan mendeskripsikan keterlaksanaan dan aktivitas siswa pada penerapan perangkat pembelajaran fisika yang berorientasi pada pendekatan discovery dengan tipe berbeda. Subyek dalam penelitian ini adalah siswa kelas X SMK Negeri 2 Sumbawa Besar semester genap tahun ajaran 2010/2011. Penelitian ini merupakan penelitian eksperimental dengan rancangan Two-Groups Pretest-Postest Design. Teknik pengumpulan data dalam penelitian ini adalah pemberian tes dan observasi. Data-data yang dikumpulkan dianalisis secara deskriptif dan menggunakan statistik inferensial. Hasil analisis data menunjukkan bahwa: (1) kemampuan kognitif, keterampilan ilmiah, dan tingkat tanggung jawab siswa setelah diberikan pembelajaran fisika melalui pendekatan pembelajaran penemuan (discovery learning) tipe less structured guided discovery lebih baik daripada tipe guided discovery; (2) keterlaksanaan pembelajaran fisika yang menggunakan perangkat pembelajaran berorientasi pada pendekatan discovery adalah 98,08\% pada kedua tipe guided discovery dan tipe less structured guided discovery; (3) aktivitas siswa selama penerapan perangkat pembelajaran fisika yang berorientasi pada pendekatan discovery menggambarkan aktivitas siswa yang sesuai dengan tahap-tahap pembelajaran discovery baik pada tipe guided discovery maupun pada tipe less strucured guided discovery; dan (4) penerapan perangkat pembelajaran fisika yang berorientasi pada pendekatan pembelajaran discovery pada kedua tipe less structured guided discovery dan tipe guided discovery terbukti dapat mengembangkan kemampuan akademik dan karakter tanggung jawab siswa.
\end{abstract}

Kata-kata Kunci: karakter tanggung jawab, kemampuan akademik, pendekatan pembelajaran penemuan

\section{PENDAHULUAN}

Fisika adalah cabang sains. Oleh karena itu hakekat fisika dapat ditinjau dan dipahami dari hakekat sains. Sains merupakan kesatuan produk, proses, dan sikap, sehingga tujuan pembelajaran fisika harus mengacu pada tiga aspek esensial, menurut Sarkin (1998: 140), yaitu membangun (1) pengetahuan berupa pemahaman, konsep, hukum, dan teori serta penerapannya; (2) kemampuan melakukan proses antara lain pengukuran, percobaan, bernalar melalui diskusi; (3) sikap keilmuan, antara lain kecenderungan keilmuan, berpikir kritis, berpikir analitis, tanggung jawab, perhatian pada masalah-masalah sains, penghargaan pada hal-hal yang bersifat sains. Berdasarkan ketiga tujuan tersebut, pendidikan fisika memiliki peran yang sangat penting dalam pembentukan kepribadian dan perkembangan intelektual anak. Menurut Rustaman (tanpa tahun), sains dianggap menduduki posisi penting dalam pembangunan karakter masyarakat dan bangsa karena kemajuan pengetahuannya yang amat pesat, keampuhan prosesnya yang dapat ditransfer pada bidang lain, serta muatan nilai dan sikap di dalamnya. Oleh 
karena itu guru dalam melaksanakan kegiatan pembelajaran di kelas harus dapat menempatkan aktivitas nyata anak dengan berbagai objek yang dipelajari. Berbagai kesempatan harus diberikan kepada anak untuk bersentuhan langsung dengan objek yang akan atau sedang dipelajarinya. Dengan kegiatan pembelajaran inilah sebenarnya anak sedang bergelut dan belajar apa yang dinamakan sains. Mereka dibimbing untuk melakukan penelusuran masalah, mencari berbagai penjelasan mengenai fenomena yang mereka temui atau alami, mengembangkan kemampuan fisiknya (motorik), dan melatih penggunaan penalaran mereka untuk mencari pemecahan masalah yang dihadapi dengan melakukan berbagai eksperimen yang relevan (Rohandi, 1998). Dengan demikian pendidikan sains bukanlah sematamata merupakan proses transfer pengetahuan guru kepada anak, melainkan sebuah proses pembentukan pengetahuan pada anak dengan bekal pengetahuan awal yang sudah ada untuk diperkaya dan diberdayakan melalui aktivitas nyata mereka yang di dalamya tentu saja sangat berkaitan dengan proses transfer nilai.

Berdasarkan hasil telaah sampel RPP mata pelajaran fisika SMK Negeri 2 Sumbawa Besar (Khaeruddin, 2006 dan Rahmi, 2009) diperoleh informasi, yaitu: (1) tidak satupun dari RPP tersebut yang secara sengaja mencantumkan hasil belajar domain afektif di dalam perencanaan pembelajarannya, (2) dalam langkah-langkah pembelajaran tidak terlihat adanya upaya terencana untuk mengembangkan karakterkarakter positif, (3) dalam kegiatan evaluasi tidak tercantum kegiatan evaluasi ranah afektif. Berdasarkan hasil wawancara dengan guru-guru fisika SMK Negeri 2 Sumbawa Besar diperoleh informasi bahwa guru-guru lebih menekankan pada bagaimana siswa bisa menguasai konsep-konsep fisika yang diajarkan sehingga bisa menjawab soal-soal di dalam ujian, sedangkan aspek afektif yakni pembentukan karakter positif belum mendapat perhatian dari guru-guru.

Tidak adanya perhatian terhadap pendidikan karakter (ranah afektif) di dalam kegiatan pembelajaran memunculkan kekhawatiran akan adanya dampak dalam jangka panjang. Dalam Kongres Guru Besar Indonesia pada tanggal 16 Mei 2007 (dalam Ibrahim, 2008: 5) menyebutkan empat dampak besar yang mungkin muncul, yaitu: (a) terjadinya erosi budi pekerti, perilaku baik, dan tingkah laku positif, (b) solidaritas dan kesetiakawanan rendah (frekuensi perkelahian dan anarkis tinggi), (c) banyak anak berhasil menghafal tetapi tidak memahami apa yang dihafalnya dan pada akhirnya (d) daya saing bangsa menjadi rendah. Mahatma Gandhi (dalam William dan Megawangi, tanpa tahun) memperingatkan tentang salah satu tujuh dosa fatal, yaitu "education without character" (pendidikan tanpa karakter). William dan Megawangi (tanpa tahun) juga mengutip pendapat Martin Luther yang menyatakan bahwa: "Intelligence plus character....that is the goal of true education" (Kecerdasan plus karakter merupakan tujuan akhir dari pendidikan sebenarnya). Juga Theodore Roosevelt (dalam William dan Megawangi, tanpa tahun) mengatakan bahwa: "To educate a person in mind and not in morals is to educate a menace to society". Roosevelt menyatakan pendidikan dalam aspek kecerdasan otak tanpa memperhatikan aspek moral adalah ancaman mara-bahaya kepada masyarakat.

Untuk menghindari dampak besar di atas diperlukan perubahan pola pikir yang digunakan sebagai landasan dalam pembelajaran. Perubahan pola pikir hendaknya memikirkan bagaimana mengembangkan insan cerdas dan berkarakter kuat melalui kegiatan pembelajaran. Guru harus fokus pada tujuan pembelajaran fisika secara utuh bukan hanya terfokus pada pencapaian tujuan pembelajaran aspek kognitif dan psikomor saja tetapi juga mengintegrasikan domain afektif ke dalam kedua domain tersebut. Salah satu cara yang dapat ditempuh adalah mengintegrasikan pendidikan karakter untuk semua mata pelajaran termasuk fisika.

Karakter-karakter positif dapat diajarkan dan dikembangkan di sekolah melalui implementasi pendidikan karakter dalam keterpaduan pembelajaran dengan semua mata pelajaran, termasuk mata pelajaran fisika. Dalam penelitian ini difokuskan pada pengembangan satu karakter saja, yaitu tanggung jawab (responsibility). Karakter tanggung jawab sangat diperlukan oleh setiap individu dalam kehidupan seharihari, termasuk dalam dunia kerja dewasa ini. Setiap individu bertanggung jawab terhadap dirinya, kelurga, masyarakat, bangsa dan agamanya. Dalam Undangundang Nomor 20 Tahun 2003 tentang Sisdiknas, disebutkan salah satu fungsi pendidikan nasional adalah membentuk warga negara yang bertanggung jawab. Menurut The Six Pillar of Character (enam pilar karakter) yang dikembangkan oleh Josephson Institut, tanggung jawab (Responsibility) memiliki ciri-ciri, yaitu: melakukan apa yang harus dilakukan, gigih, selalu melakukan yang terbaik, menerapkan kendali diri, disiplin, berpikir sebelum bertindak, dan bertanggung jawab terhadap pilihannya.

Di samping masalah ranah afektif yang kurang diperhatikan, masalah yang lain dalam pembelajaran fisika adalah lemahnya kemampuan proses sains siswa, hal ini tercermin dari hasil TIMSS (Third International in Mathematics and Science Study) yang menunjukkan kemampuan siswa Indonesia dalam bidang IPA berada pada urutan ke-38 dari 40 negara (Depdiknas, 2007). Hal ini salah satunya disebabkan oleh pembelajaran sains selama ini lebih berorientasi pada isi materi sains daripada berorientasi pada proses sains, dimana guru 
jarang melatihkan keterampilan-ketermpilan proses sains kepada peserta didik. Berdasarkan hasil wawancara kami dengan guru-guru fisika SMK Negeri 2 Sumbawa Besar diperoleh informasi bahwa guru-guru tidak perna melatihkan keterampilan proses sains terpadu kepada siswa, sedangkan keterampilan proses sains dasar hanya perna dilatihkan ketika mempelajari materi besaran dan satuan.

Untuk mengatasi dua kondisi di atas maka diperlukan suatu pendekatan pembelajaran yang sesuai untuk mengembangkan karakter, meningkatkan kemampuan kognitif dan keterampilan proses sains siswa. Salah satu pendekatan yang dapat digunakan adalah pendekatan pembelajaran penemuan (Discovery). Alasan pemilihan pendekatan ini adalah pertama, pendekatan pembelajaran penemuan merupakan pendekatan pembelajaran yang berpusat pada siswa. Menurut Efendy (2011), karakter-karakter positif cenderung lebih mudah dibentuk apabila pembelajaran IPA menggunakan pendekatan yang berpusat pada siswa (student centered) dibandingkan berpusat pada guru (teacher centered). Senada dengan pendapat Effendy

\section{Kelas Less Structured Guided Discovery :}

\section{Kelas Guided Discovery}

Subjek penelitian adalah siswa kelas X SMK Negeri 2 Sumbawa Besar. Dengan cara random dipilih dua kelas eksperimen, yaitu kelas $\mathrm{X}$ TAB (tipe less structured guided discovery) dan $\mathrm{X} \mathrm{TKR}_{2}$ (tipe guided discovery).

Dalam penelitian ini yang menjadi vaariabel manipulasi adalah tipe pendekatan pembelajaran discovery; variable respon adalah kemampuan kognitif, keterampilan ilmiah, dan tingkat tanggung jawab siswa; dan variabel kontrol adalah jenis instrumen, kualifikasi guru yang mengajar, materi pelajaran, dan durasi waktu mengajar.

Penelitian ini terdiri dari dua tahapan utama, yaitu pertama, tahapan pengembangan perangkat dan kedua, tahap pengembangan perlakuan (eksperimen). Tahaptahap pengembangan perangkat diadaptasi dari model pengembangan Four-D yang dikembangkan oleh Thiagarajan, Semmel dan Semmel (1974). Dalam tahap pengembangan ini dihasilkan perangkat pembelajaran yang berorientasi pada pendekatan pembelajaran discovery dengan dua tipe, yaitu perangkat pembelajaran yang beorientasi pada tipe less structured guided discovery dan perangkat pembelajaran yang beorientasi pada tipe guided discovery. Perangkat yang telah dikembangkan telah divalidasi oleh pakar di bidang Pendidikan IPA, direvisi oleh peneliti dan diujicoba pada sampel terbatas. Berdasarkan hasil validasi pakar dan
Mulyana (2004) menyatakan bahwa di dalam pendekatan pembelajaran yang melibatkan peserta didik sepenuhnya pada suatu aktivitas belajar, peserta didik didorong untuk melakukan refleksi diri, bereaksi, menetukan akibat tindakan, dan membuat keputusan yang relevan dengan situasi belajar. Kedua, pendekatan pembelajaran penemuan merupakan pendekatan pembelajaran yang berbasis inkuiri. Prince dan Felder (2006) menyatakan bahwa:

"Discovery learning is an inquiry-based approach in which students are given a question to answer, a problem to solve, or a set of observations to explain, and then work in a largely self directed manner to complete their assigned tasks and draw approriate inferences from the outcomes, "discovering" the desired factual and conceptual knowledge in the process."

\section{METODE PNELITIAN}

Penelitian yang dilakukan merupakan penelitian eksperimental dengan rancangan penelitian Two-Groups Pretest-Posttest Design seperti pada gambar berikut ini.

hasil uji coba diperoleh informasi bahwa seluruh perangkat yang $\mathrm{X}_{1}$ telah dikembangkan layak untuk diimplementasikan di lapangan.

$\mathrm{R}$ Tăap pexgembangan perlakuan (eksperimen) dalam penelitian adalah: (1) menentukan sampel penelitian; (2) memberikan pretes (THB dan tes keterampilan ilmiah) dan melakukan observasi tingkat tanggung jawab siswa sebelum perlakuan; (3) memberikan perlakuan. Selama perlakuan dilakukan observasi keterlaksnaan pembelajaran, aktivitas siswa dan tingkat tanggung jawab siswa; (4) memberikan posttest.

Instrumen yang digunakan dalam penelitian ini adalah Tes Hasil Belajar (THB), tes keterampilan ilmiah, lembar penilaian tingkat tanggung jawab, lembar pengamatan keterlaksanaan pembelajaran, dan lembar penilaian aktivitas siswa. Seluruh instrument yang digunakan dalam penelitian ini valid dan reliabel.

Teknik pengumpulan data dalam penelitian ini adalah pemberian tes dan observasi. Tes dilakukan dua kali, yaitu pretest dan posttest. Obervasi tingkat tanggung jawab dilakukan dua kali, yaitu satu sebelum eksperimen dan selama eksperimen, sedangkan observasi keterlaksanaan pembelajaran dan aktivitas siswa dilakukan selama eksperimen.

Untuk menguji hipotesis penelitian, data-data kemampuan kognitif, keterampilan ilmiah dan tingkat tanggung jawab siswa dianalisis menggunakan statistik inferensial, yaitu uji parametrik dengan menggunakan the t-test for independent sample. Dua asumsi dasar dalam menggunakan uji parametrik (uji-t), yaitu distribusi dari variabel adalah normal dan kedua populasi dimana 
sampel tersebut ditarik mempunyai varians yang sama (Nazir, 1999). Uji normalitas dilakukan dengan menggunakan uji One-Sample Kolmogorov-Smirnov, sedangkan uji homogenitas data dilakukan dengan menggunakan Uji Levene. Jika salah satu dari kedua asumsi dasar tersebut tidak terpenuhi, maka uji hipotesis dilakukan dengan menggunakan uji non parametrik, yatiu uji U Mann-Whitney.

Ketuntasan Tujuan Pembelajaran Khusus (TPK), ketuntasan belajar per siswa pada domain produk dan proses, tingkat tanggung jawab siswa, dan aktivitas siswa dalam kegiatan pembelajaran discovery pada kedua tipe less structurd guided discovery dan tipe guided discovery dianalisis secara deskriptif kualitatif, sedangkan data keterlaksanaan pembelajaran discovery pada kedua tipe dianalisis secra deskriptif kuantitatif.

\section{HASIL PENELITIAN}

Keterlaksanaan Pembelajaran Discovery

Hasil pengamatan keterlaksanaan pembelajaran secara ringkas dapat dilihat pada Tabel 1 berikut ini.

Tabel 1 Data keterlaksanaan pembelajaran discovery

\begin{tabular}{|c|cccc}
\multirow{2}{*}{ No } & \multicolumn{1}{c}{ Tipe } & \multicolumn{3}{c}{ Keterlaksanaan Pembelajaran (\%) } \\
& & Pert. 1 & Pert. 2 & Rata-rata \\
\hline 1 & Less Structured Guided Discovery & 96,15 & 100,00 & 98,08 \\
2 & Guided Discovery & 100,00 & 96,15 & 98,08 \\
\hline
\end{tabular}

Berdasarkan Tabel 1 diperoleh informasi bahwa hamper seluruh tahap-tahap pembelajaran discovery pada kedua tipe dilaksanakan oleh guru.

\section{Aktivitas Siswa Selama Kegiatan Pembelajaran Discovery}

Tabel 2 Data Aktivitas Siswa dalam Kegiatan Pembelajaran Discovery

$\begin{gathered}\text { Tipe Pendekatan Pembelajaran } \\ \text { discovery }\end{gathered}$
Relevan Structured Guided Discovery
Guided Discovery
Berdasarkan Tabel 2 di atas dapat disimpulkan
98.8
bahwa aktivitas siswa dalam kegiatan pembelajaran
discovery mencerminkan aktivitas yang sesuai dengan
tahap-tahap pembelajaran discovery pada baik pada tipe
less structured guided discovery maupun pada tipe
guided discovery.

Persentase Aktivitas (\%) Relevan Tidak Relevan 99.65 98.82 0.35

1.18 pembelajaran discovery tipe Less structured guided discovery secara ringkas dapat dilihat pada Tabel 2 berikut ini.

\section{Kemampuan Kognitif Siswa}

\section{Deskripsi Data Kemampuan Kognitif Siswa}

Tabel 3 Ketuntasan Tujuan Pembelajaran Khusus (TPK) Kemampuan Kognitif pada Pembelajaran Discovery

$\begin{array}{clcc}\text { No } & \text { Tipe Pendekatan pembelajaranDiscovery } & \text { Jumlah TPK } & \begin{array}{c}\text { Jumlah TPK yang } \\ \text { tuntas }\end{array} \\ (\mathrm{P} \geq 0,70)\end{array}$

Tabel 4 Ketuntasan Individual Kemampuan Kognitif pada Pembelajaran Discovery

\begin{tabular}{|c|c|c|c|c|c|c|}
\hline No & Tipe & $\begin{array}{c}\text { Nilai } \\
\text { rata-rata }\end{array}$ & $\begin{array}{l}\text { Pretest } \\
\text { Persentase siswa } \\
\text { yang mencapai } \\
\text { ketuntasan belajar } \\
\qquad(\%)\end{array}$ & $\begin{array}{l}\text { Nilai rata- } \\
\text { rata }\end{array}$ & $\begin{array}{l}\text { Posttest } \\
\text { Persentase siswa } \\
\text { yang mencapai } \\
\text { ketuntasan belajar } \\
\qquad(\%)\end{array}$ & $\begin{array}{c}\text { Gain } \\
\text { rata-rata }\end{array}$ \\
\hline 1 & $\begin{array}{l}\text { Less Structured Guided } \\
\text { Discovery }\end{array}$ & 4.65 & 0.00 & 94.39 & 100.00 & 89.74 \\
\hline 2 & Guided Discovery & 4.33 & 0.00 & 71,24 & 60.00 & 66,66 \\
\hline
\end{tabular}


Berdasarkan Tabel 3 dan 4 dapat disimpulkan bahwa pembelajaran fisika dengan menerapkan perangkat pembelajaran yang berorientasi pada pembelajaran discovery pada kedua tipe less structured guided discovery dan tipe guided discovery terbukti dapat mengembangkan kemampuan kognitif siswa.

\section{Uji Hipotesis}

Tabel 5 Hasil Uji Normalitas dan Homogenitas Data Kemampuan Kognitif Siswa

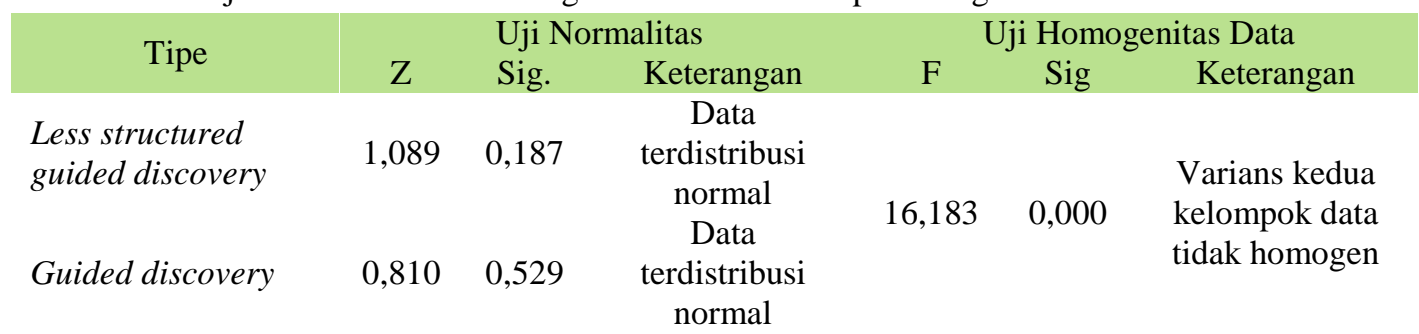

Berdasarkan hasil uji noramlitas dan homogenitas data diperoleh bahwa salah satu asumsi dasar dalam menggunakan uji parametrik tidak terpenuhi, yaitu varian kedua kelompok data tidak homogen, sehingga uji hipotesis dilakukan dengan menggunakan uji non parametrik, yaitu dengan uji U Mann-Whitney dengan rincian sebagai berikut:

- Hipotesis:

$$
\begin{array}{ll}
\mathrm{H}_{0} & : \mu_{1} \leq \mu_{2} \\
\mathrm{Ha} & : \mu_{1}>\mu_{2} \\
\alpha & : 0,05
\end{array}
$$

Dimana $\mu_{1}$ adalah mean nilai peningkatan (gain score) kemampuan kognitif siswa kelas less structured guided discovery (kelas LSGD) dan $\mu_{2}$ adalah mean nilai peningkatan (gain score) kemampuan kognitif siswa kelas guided discovery (kelas GD). Kaedah pengujian adalah $\mathrm{H}_{0}$ ditolak jika Sig. $<\alpha$.

- Dengan menggunakan SPPS 16.0 diperoleh hasil

\begin{tabular}{|c|c|c|c|c|c|c|c|c|}
\hline $\begin{array}{c}\text { Tipe } \\
\text { Pembelajaran } \\
\text { Discovery }\end{array}$ & $\mathbf{N}$ & $\begin{array}{l}\text { Mean } \\
\text { Rank }\end{array}$ & $\begin{array}{c}\text { Sum } \\
\text { of } \\
\text { Ran } \\
k\end{array}$ & $\begin{array}{c}\text { Mann- } \\
\text { Whitney U }\end{array}$ & $\begin{array}{c}\text { Wilcxon } \\
\text { W }\end{array}$ & $\mathbf{Z}$ & $\begin{array}{c}\text { Sign } \\
(1-\text { tailed })\end{array}$ & Ket. \\
\hline $\begin{array}{l}\text { Less strucrured } \\
\text { guided discovery } \\
\text { Guided discovery }\end{array}$ & 16 & 27,97 & $\begin{array}{c}447 \\
50 \\
218 \\
50\end{array}$ & 8,500 & 218,500 & $-4,828$ & 0,000 & $\begin{array}{c}\mathrm{H}_{0} \text { ditolak } \\
\text { dan } \mathrm{H}_{\mathrm{a}} \\
\text { diterima }\end{array}$ \\
\hline
\end{tabular}
analisis seperti pada Tabel 6 berikut ini.

Tabel 6 Hasil Uji U Mann-Whitney Data Kemampuan Kognitif Siswa

- Berdasarkan hasil analisis pada Tabel 6 diperoleh Sig. = 0,000. Karena Sig. $<\alpha(0,000<0,05)$, maka $\mathrm{H}_{0}$ ditolak dan $\mathrm{H}_{\mathrm{a}}$ diterima.

- Kesimpulannya adalah kemampuan kognitif siswa setelah diberikan pembelajaran melalui pendekatan discovery tipe less structured guided discovery lebih baik daripada tipe guided discovery.

\section{Keterampilan Ilmiah Siswa}

Deskripsi Data Keterampilan Ilmiah Siswa

Deskripsi data keterampilan ilmiah siswa setelah proses pembelajaran dengan menggunakan perangkat pembelajaran yang berorientasi pendekatan discovery pada tipe less structured guided discovery dan tipe guided discovery dapat dilihat pada Tabel 7 dan 8 berikut ini.

Tabel 7 Ketuntasan Tujuan Pembelajaran Khusus (TPK) Keterampilan Ilmiah pada Pembelajaran Discovery

\begin{tabular}{clcc} 
No & \multicolumn{1}{c}{ Tipe Pendekatan pembelajaranDiscovery } & Jumlah TPK & $\begin{array}{c}\text { Jumlah TPK yang } \\
\text { tuntas }\end{array}$ \\
$(\mathrm{P} \geq 0,70)$
\end{tabular}

Tabel 8 Ketuntasan Individual Keterampilan ilmiah Siswa pada Pembelajaran Discovery

\begin{tabular}{l|l|lll} 
No & Tipe & Pretest & Posttest & Gain \\
Nilai & Persentase siswa & Nilai rata- & Persentase siswa & rata-rata
\end{tabular}




\begin{tabular}{|c|c|c|c|c|c|c|}
\hline & & rata-rata & $\begin{array}{c}\text { yang mencapai } \\
\text { ketuntasan belajar } \\
(\%)\end{array}$ & rata & $\begin{array}{c}\text { yang mencapai } \\
\text { ketuntasan belajar } \\
(\%)\end{array}$ & \\
\hline 1 & $\begin{array}{l}\text { Less Structured Guided } \\
\text { Discovery }\end{array}$ & 23,88 & 0.00 & 91,74 & 93,75 & 67,86 \\
\hline 2 & Guided Discovery & 23,93 & 0.00 & 62,14 & 60.00 & 38,21 \\
\hline
\end{tabular}

Berdasarkan Tabel 7 dan 8 dapat disimpulkan bahwa pembelajaran fisika dengan menerapkan perangkat pembelajaran yang berorientasi pada pendekatan pembelajaran discovery pada kedua tipe less structured guided discovery dan tipe guided discovery terbukti dapat mengembangkan keterampilan ilmiah siswa.
Data-data nilai peningkatan (gain) keterampilan ilmiah digunakan untuk melakukan uji hipotesis kedua dalam penelitian ini. Sebelum pengujian hipotesis dilakukan, maka terlebih dahulu dilakukan pengujian normalitas dan homogenitas data. Dengan bantuan SPSS 16.0, diperoleh ringkasan hasil uji normalitas dan uji homogenitas data seperti pada pada Tabel 9 berikut ini.

\section{Uji Hipotesis}

Tabel 9 Hasil Uji Normalitas dan Homogenitas Data Keterampilan Ilmiah Siswa

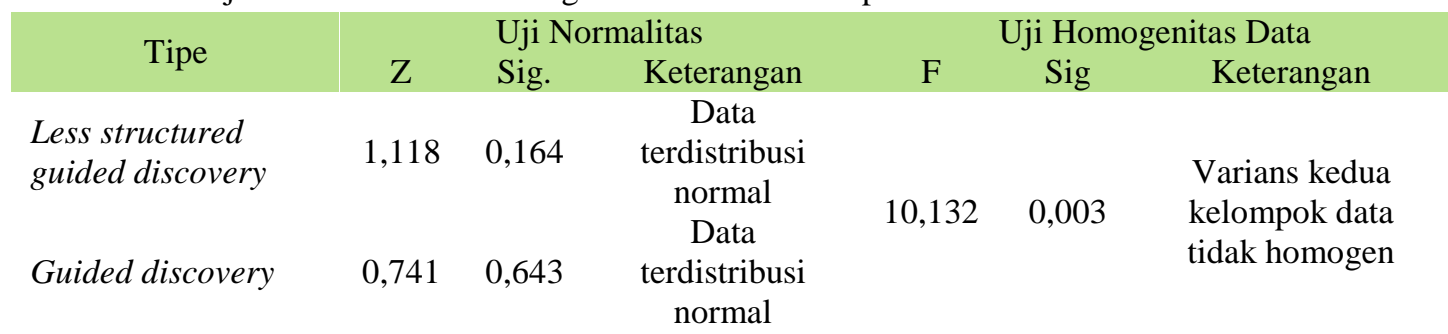

Berdasarkan hasil uji normalitas dan homogenitas data diperoleh bahwa salah satu asumsi dasar dalam menggunakan uji parametrik tidak terpenuhi, yaitu uji hipotesis dilakukan dengan menggunakan uji non parametrik, yaitu dengan uji U Mann-Whitney dengan hasil analisis seperti pada Tabel 10 berikut ini. varian kedua kelompok data tidak homogen, sehingga

Tabel 10 Hasil Uji U Mann-Whitney Data Keterampilan Ilmiah Siswa

\begin{tabular}{|c|c|c|c|c|c|c|c|c|}
\hline $\begin{array}{c}\text { Tipe } \\
\text { Pembelajaran } \\
\text { Discovery }\end{array}$ & $\mathbf{N}$ & $\begin{array}{l}\text { Mean } \\
\text { Rank }\end{array}$ & $\begin{array}{c}\text { Sum of } \\
\text { Rank }\end{array}$ & $\begin{array}{c}\text { Mann- } \\
\text { Whitney } \\
\text { U }\end{array}$ & $\begin{array}{c}\text { Wilcxon } \\
\text { W }\end{array}$ & $\mathbf{Z}$ & $\begin{array}{c}\text { Sign } \\
\text { (1-tailed) }\end{array}$ & Ket. \\
\hline $\begin{array}{l}\text { Less strucrured } \\
\text { guided discovery } \\
\text { Guided discovery }\end{array}$ & $\begin{array}{l}16 \\
20\end{array}$ & $\begin{array}{l}26,16 \\
12,38\end{array}$ & $\begin{array}{l}418,50 \\
247,50\end{array}$ & 37,500 & 247,500 & $-3,920$ & 0,000 & $\begin{array}{c}\mathrm{H}_{0} \text { ditolak } \\
\text { dan } \mathrm{H}_{\mathrm{a}} \\
\text { diterima }\end{array}$ \\
\hline
\end{tabular}

- Berdasarkan hasil analisis pada Tabel 10 diperoleh Sig. $=0,000$. Karena Sig. $<\alpha(0,000<0,05)$, maka $\mathrm{H}_{0}$ ditolak dan $\mathrm{H}_{\mathrm{a}}$ diterima.

- Kesimpulannya adalah keterampilan ilmiah siswa setelah diberikan pembelajaran melalui pendekatan discovery tipe less structured guided discovery lebih baik daripada tipe guided discovery.

\section{Tingkat Tanggung Jawab Siswa} Deskripsi Data Tanggung Jawab Siswa

Data tingkat tanggung jawab siswa dalam kegiatan pembelajaran discovery pada masing-masing tipe dapat dilihat pada Tabel 11 berikut ini.

Tabel 11 Data Tingkat Tanggung Jawab Siswa dalam Kegiatan Pembelajaran Fisika yang Beorientasi pada Pendekatan Pembelajaran Penemuan

\begin{tabular}{|clccccc}
\hline \multirow{2}{*}{ No } & \multicolumn{1}{c}{ Tipe } & \multicolumn{2}{c}{ Pretest } & \multicolumn{2}{c}{ Posttest } & Gain \\
& $\begin{array}{c}\text { Persentase } \\
\text { rata-rata }\end{array}$ & Kategori & $\begin{array}{c}\text { Persentase } \\
\text { rata-rata }\end{array}$ & Kategori & $\begin{array}{c}\text { rata-rata } \\
1\end{array} \begin{array}{l}\text { Less Structured Guided } \\
\text { Discovery }\end{array}$ \\
$\begin{array}{l}\text { Guided Discovery } \\
2\end{array}$ & 66.50 & $\mathrm{~T}$ & 88.44 & $\mathrm{ST}$ & 21.94 \\
& 62.40 & $\mathrm{~T}$ & 67.21 & $\mathrm{~T}$ & 4.81
\end{tabular}

Berdasarkan Tabel 11 diperoleh informasi bahwa pembelajaran fisika dengan menerapkan perangkat pembelajaran yang berorientasi pada pendekatan pembelajaran discovery pada kedua tipe less structured 
guided discovery dan tipe guided discovery terbukti dapat mengembangkan karakter tanggung jawab siswa.

\section{Uji Hipotesis}

Data-data nilai peningkatan (gain) tingkat tanggung jawab digunakan untuk melakukan uji hipotesis ketiga Tabel 12 Hasil Uji Normalitas dan Homogenitas Data Tingkat tanggung Jawab Siswa

\begin{tabular}{|cccc}
\multicolumn{1}{c}{ Tipe } & \multicolumn{3}{c}{ Uji Normalitas } \\
Sig. & $\begin{array}{c}\text { Keterangan } \\
\text { Data }\end{array}$ \\
$\begin{array}{l}\text { Less structured } \\
\text { guided discovery }\end{array}$ & 0,476 & 0,977 & $\begin{array}{c}\text { terdistribusi } \\
\text { normal } \\
\text { Data }\end{array}$ \\
Guided discovery & 0,816 & 0,518 & $\begin{array}{c}\text { terdistribusi } \\
\text { normal }\end{array}$
\end{tabular}

Berdasarkan hasil uji noramlitas dan homogenitas data diperoleh bahwa kedua asumsi dasar dalam menggunakan uji parametrik terpenuhi, sehingga uji hipotesis dilakukan dengan menggunakan t-test for independent sample dengan rincian sebagai berikut:

- Hipotesis:

Tabel 4.34 Hasil t-test for Independent Sample Gain Data Tingkat Tanggung Jawab Siswa

\begin{tabular}{|lcc|c|cc|c|}
\multicolumn{1}{|c|}{ Tipe Pembelajaran Discovery } & N & Mean & $\begin{array}{c}\text { Standar } \\
\text { Deviasi }\end{array}$ & t & $\begin{array}{c}\text { Sign. } \\
\text { (1-tailed) }\end{array}$ & Keterangan \\
$\begin{array}{l}\text { Less Structured guided discovery } \\
\text { Guided discovery }\end{array}$ & 16 & 21,942 & 11,114 & 5,163 & 0,000 & $\mathrm{H}_{0}$ ditolak dan $\mathrm{H}_{\mathrm{a}}$ \\
diterima
\end{tabular}

- Pada SPSS 16.0 tidak tersedia fasilitas untuk mengatur uji signifikansi (1-tailed dan 2-tailed) dan pada output uji hanya muncul nilai Sig. untuk dua pihak (2-tailed). Untuk menentukan nilai Sig. satu pihak (1-tailed) dapat dilakukan dengan membagi dua nilai Sig. (2-tailed). Berdasarkan hasil analisis pada Tabel 4.34 diperoleh Sig. (2-tailed) = 0,00 , jika dibagi 2 maka diperoleh Sig. $(1$-tailed $)=$ 0,00 . Karena Sig. $(1$-tailed $)<\alpha(0,00<0,05)$, maka $\mathrm{H}_{0}$ ditolak dan $\mathrm{H}_{\mathrm{a}}$ diterima.

- Kesimpulannya adalah tingkat tanggung jawab siswa dalam kegiatan pembelajaran melalui pendekatan discovery tipe less structured guided discovery lebih baik daripada tipe guided discovery.

\section{DISKUSI HASIL PENELITIAN}

\section{Keterlaksanaan Pembelajaran Discovery}

Berdasarkan data keterlaksanaan pembelajaran pada tabel 1 diperoleh informasi bahwa keterlaksanaan pembelajaran discovery tipe less structured guided discovery dan tipe guided discovery adalah masingmasing 98,08\%. Ketercapaian persentase keterlaksanaan pembelajaran ini diakibatkan oleh beberapa faktor, yaitu: (1) Pembelajaran discovery pada kedua tipe direncanakan dengan baik dan sistematis, hal ini terlihat dengan tersedianya perangkat pembelajaran yang dalam penelitian ini. Sebelum pengujian hipotesis dilakukan, maka terlebih dahulu dilakukan pengujian normalitas dan homogenitas data. Dengan bantuan SPSS 16.0, diperoleh ringkasan hasil uji normalitas dan uji homogenitas data seperti pada Tabel 12 berikut ini.

$$
\begin{array}{ll}
\mathrm{H}_{0} & : \mu_{1} \leq \mu_{2} \\
\mathrm{Ha} & : \mu_{1}>\mu_{2}
\end{array}
$$

a Uji U.,

$\mathrm{F}_{\text {Dimana }} \mathrm{Sig}_{\mathrm{H}_{1}}$ adalah Keterangan mean nilai peningkatan (gain score) tingkat tanggung jawab siswa kelas less structured guided Varians e ked (kelas LSGD) dan $\mu_{2}$ 0,870 adah 0,358 mean nilai pelompok data tanggung jawab siswa kelas guided discovery (kelas GD). Kaedah pengujian adalah $\mathrm{H}_{0}$ ditolak jika Sig.< $\alpha$.

- Dengan menggunakan SPPS 16.0 diperoleh hasil analisis seperti pada Tabel 4.34 berikut ini. memiliki kualitas yang baik serta alat dan bahan yang dibutuhkan selama kegiatan pembelajaran. Perencanaan pembelajaran yang baik merupakan salah satu faktor keberhasilan suatu proses pembelajaran. (2) LKS yang digunakan dalam kegiatan pembelajaran penemuan dilengkapi dengan definisi-definisi dari keterampilan ilmiah (keterampilan proses sains terpadu) yang akan digunakan siswa dalam kegiatan penemuan konsep/prinsip, sehingga akan membantu siswa dalam tahap-tahap awal pembelajaran. Bantuan semacam ini dikenal dengan istilah scaffolding. (3) Penguasaan guru terhadap seluruh perangkat yang telah dikembangkan peneliti dan komitmen yang tinggi untuk melaksanakan pembelajaran sesuai dengan perangkat yang telah dikembangkan. Penguasaan guru terhadap perangkat pembelajaran tentu terwujud melalui diskusi dan latihan penerapan seluruh perangkat ini secara sungguhsungguh, dan (4) adanya masukan-masukan dari pelaksanaan uji coba perangkat dalam sampel terbatas, sehingga kelemahan-kelemahan dalam pelaksanaan pembelajaran pada kegiatan uji coba perangkat dapat dikurangi seoptimal mungkin.

Tahap pembelajaran yang tidak dilaksanakan pada tipe less structured guided discovery, yaitu pada pertemuan pertama, guru tidak mengingatkan siswa untuk mengerjakan tugas rumah sebagaimana yang 
tercantum pada LKS, sedangkan tahap pembelajaran yang tidak dilakasanakan pada tipe guided discovery, yaitu pada pertemuan kedua, guru tidak melakukan apersepsi.

\section{Aktivitas Siswa Selama Kegiatan Pembelajaran Discovery}

Berdasarkan Tabel 2 diperoleh informasi bahwa aktivitas siswa dalam kegiatan pembelajaran telah mencerminkan aktivitas yang sesuai dengan tahap-tahap pembelajaran discovery baik pada tipe guided discovery maupun pada tipe less structured guided discovery. Tercerminkan aktivitas siswa sebagai aktivitas yang sesuai dengan tahap-tahap pembelajaran discovery untuk kedua tipe disebabkan oleh salah satunya adalah keterlaksanaan RPP pada masing-masing tipe adalah 98,08, dimana hampir seluruh tahap pembelajaran terlaksana. Keterlaksanaan pembelajaran discovery sebagaimana yang tertuang dalam RPP tentu akan meningkatkan aktivitas siswa selama proses pembelajaran, hal ini sesuai dengan pernyataan Piaget dan Dewey (dalam Castranova, tanpa tahun), "Discovery learning encompasses an instructional model and strategies that focus on active, hands-on learning opportunities for students." pembelajaran penemuan (discovery learning) menekankan pada keterlibatan aktif siswa dalam kegiatan pembelajaran. Senada dengan pernyataan Piaget, Bruner (dalam Carin, 1993) menyatkan bahwa: "The only way people learn discovery techniques is by having opportunities to discover them by themselves." Dengan pembelajaran discovery seseorang memiliki kesempatan yang luas untuk membangun pengetahuan mereka oleh diri mereka sendiri, sehingga potensi intelektualnya akan meningkat. Dari kedua pernyataan tersebut jelas bahwa jika persentase keterlaksanaan pembelajaran discovery tinggi, maka aktivitas pembelajaran siswa dalam kegiatan pembelajaran penemuan akan meningkat karena dalam pembelajaran discovery siswa terlibat aktif dalam menemukan konsep/prinsip fisika melalui melalui kegiatan eksplorasi dan pembentukan konsep, kemudian menerapkan konsep tersebut untuk menyelesaikan masalah-masalah yang diberikan. Selama proses pembelajaran siswa diberikan kebabasan untuk menemukan konsep/prinsip oleh diri mereka sendiri dan mendapatkan bimbingan agar pembentukan konsep menjadi lebih bermakna. Disamping persentase keterlaksanaan pembelajaran yang tinggi, lingkungan belajar yang terbangun dalam pembelajaran discovery tidak kaku, sehingga anak memiliki kebebasan yang terbimbing untuk melakukan aktivitas penemuannya, sehingga motivasi belajar mereka akan meningkat yang tentunya akan berdampak pada aktivitas siswa selama pembelajaran. Bruner (dalam Carin, 1993: 93) percaya bahwa salah satu implikasi dari keberhasilan pembelajaran discovery adalah siswa mendapatkan getaran kepuasan intelektual, suatu reward berupa kepuasan intrinsik. Getaran kepuasan intelaktuan ini merupakan motivasi intrinsik yang mampu mendorong siswa untuk meningkatkan aktivitas belajarnya dalam kegiatan pembelajaran penemuan.

\section{Kemampuan Kognitif Siswa}

Berdasarkan Tabel 3 diperoleh informasi bahwa penerapan pembelajaran dengan menggunakan perangkat pembelajaran yang berorientasi pendekatan penemuan tipe less structured guided discovery dapat menuntaskan seluruh Tujuan Pembelajaran Khusus (TPK) aspek produk, sedangkan pada tipe guided discovery satu TPK tidak dapat mencapai ketuntasan, yaitu TPK yang berbunyi "Diberikan persoalan fisika, siswa dapat menerapkan hukum Archimedes untuk menyelesaikan persoalan tersebut sesuai dengan kriteria penilaian pada pedoman penskoran". Dengan melihat jawaban-jawaban siswa, ditemukan kesamaan kesulitan yang dihadapi siswa, yaitu siswa tidak dapat menghubungkan persamaan $F_{b}=w_{u}-w_{z c}$ dengan rumus $F_{b}=\rho g v_{f}$ untuk mencari besarnya $\mathrm{v}_{\mathrm{f}}$ dan menggunakan nilai besaran ini untuk mencari berat beban pada zat cair lain jika volume yang tercelup sama dengan pada zat cair sebelumnya. Jika dikaitkan dengan teori perkembangan kognitif Piaget, kesulitan yang dihadapi siswa ini menunjukkan bahwa combinatorial reasoning siswa masih lemah. Combinatorial reasoning berkaitan dengan kemampuan siswa untuk menyelesaikan masalah-masalah yang melibatkan banyak variabel dalam satu waktu. Jika diperhatikan usia subjek penelitian (kelas X), tahap berfikir mereka sudah mencapai tahap berfikir operasional formal. Piaget (dalam Wadsworth, 1984) menyebutkan konten pemikiran formal adalah propositional, or combinatorial operation dan formal operation scheme. Rendahnya combinatorial reasoning siswa ini diduga disebabkan karena selama ini siswa jarang diberikan soal-soal pada dimensi pengetahual konseptual level proses kognitif menganalisis.

Berdasarkan Tabel 4 diperoleh informasi bahwa pada tipe less structured guided discovery $100 \%$ siswa mencapai ketuntasan belajar dengan nilai rata-rata kelas adalah 94,39 dan gain score rata-rata 89,74, sedangkan pada tipe guided discovery $60 \%$ siswa mencapai ketuntasan belajar dengan nilai rata-rata kelas adalah 71,24 dan gain score rata-rata 66,66. Dengan demikian, pembelajaran fisika dengan menerapkan perangkat pembelajaran yang berorientasi pada pendekatan pembelajaran discovery pada kedua tipe less structured guided discovery dan tipe guided discovery terbukti dapat mengembangkan kemampuan kognitif siswa. Dari hasil telaah jawaban siswa diperoleh informasi bahwa 
siswa-siswa yang tidak tuntas pada kelas tipe guided discovery mengalami kesulitan dalam kemampuan combinatorial reasoning sebagaimana yang telah dibahas pada paragraf sebelumnya. Oleh karena itu siswa perlu diberikan latihan soal-soal yang variatif dalam jumlah yang cukup sehingga aktivitas berfikir siswa pada tahap penerapan konsep ini meningkat, peningkatan aktivitas berfikir ini tentu akan berdampak pada kemampuan kognitif siswa. Menurut Bruner (dalam Carin, 1993): "an individual learn and develops his or her mind only by using it", artinya potensi intelektual seseorang akan berkembang hanya jika ia menggunakan potensi tersebut. Dengan demikian anak belajar terbaik jika fikiran mereka bekerja terhadap apa yang dipelajari. Pendekatan discovery merupakan pendekatan pengajaran yang mendorong siswa untuk menemukan prinsip-prinsip untuk diri mereka sendiri. Bruner (dalam Carin, 1993) mengungkapkan bahwa: "The only way people learn discovery techniques is by having opportunities to discover them by themselves." Melalui pendekatan pembelajaran penemuan seseorang memiliki kesempatan yang luas untuk membangun pengetahuan mereka oleh diri mereka sendiri, sehingga potensi intelektualnya akan meningkat. Bruner percaya bahwa anak belajar terbaik jika siswa terlibat aktif dalam kegiatan hands-on dan minds-on.

Berdasarkan hasil pengujian hipotesis, Kemampuan kognitif siswa setelah diberikan pembelajaran melalui pendekatan discovery tipe less structured guided discovery lebih baik daripada tipe guided discovery. Hasil ini sejalan dengan apa yang diungkapkan oleh Carin (1993) tentang aktivitas berfikir siswa pada masing-masing tipe. Menurut carin (1993), pada pendekatan pembelajaran discovery tipe guided discovery, guru mengajukan rumusan masalah dan metode yang dapat digunakan oleh siswa untuk menyelesaikan masalah, kemudian siswa didorong untuk menyelesaikan masalah tersebut berdasarkan metode yang telah diberikan oleh guru, sedangkan pada pendekatan pembelajaran discovery tipe less structured guided discovery, guru hanya mengajukan rumusan masalah tanpa memberikan metode pemecahan masalah, kemudian siswa ditugaskan untuk merumuskan sendiri metode pemecahan masalah dan menggunakan metode tersebut untuk memecahkan masalah yang telah diberikan setelah mendapat persetujuan guru. Aktivitas berpikir yang dilakukan siswa pada tipe less structured guided discovery lebih tinggi dibandingkan pada tipe guided discovery. Aktivitas berfikir siswa dapat dikaitkan dengan pernyataan Bruner (dalam carin, 1993: 93) yang menyatakan bahwa potensi intelektual seseorang akan berkembang hanya jika ia menggunakan potensi tersebut, artinya semakin banyak aktivitas berfikir yang dilakukan oleh seseorang maka potensi intelektualnya akan semakin tinggi. Potensi intelektual ini secara langsung berkaitan dengan tingkat pemahaman mereka terhadap materi sains, sehingga semakin tinggi aktivitas berfikir seseorang maka kemampuan kognitifnya akan semakin baik. Dengan demikian, kemampuan kognitif siswa setelah diberikan pembelajaran melalui pendekatan discovery tipe less structured guided discovery lebih baik daripada tipe guided discovery sebagaimana yang ditunjukkan dari hasil pengujian hipotesis.

\section{Keterampilan Ilmiah}

Berdasarkan Tabel 8 diperoleh informasi bahwa penerapan pembelajaran dengan menggunakan perangkat pembelajaran yang berorientasi pendekatan penemuan tipe less structured guided discovery dapat menuntaskan seluruh Tujuan Pembelajaran Khusus (TPK) aspek proses, sedangkan pada tipe guided discovery ada dua TPK yang tidak dapat mencapai ketuntasan, yaitu TPK nomor 4 yang berbunyi: "siswa dapat menyusun definisi operasional variabel" dan TPK nomor 5 yang berbunyi: "Berdasarkan definisi operasional variabel serta alat dan bahan yang disajikan dalam soal, siswa dapat menyusun prosedur percobaan". Ketidaktuntasan TPK nomor 4 ini sejalan dengan hasil temuan Nur (dalam Nur et al, 2010) yang menyatakan bahwa siswa SMP dan SMA tampak asing dengan tugas perumusan definisi operasional variabel, bahkan guru sendiri ternyata juga belum menguasai bagaimana cara merumuskan definisi operasional variabel. Ketidaktuntasan TPK nomor 4 terjadi karena kemampuan menyusun definisi operasional variabel adalah keterampilan proses sains yang level kognitifnya berada pada level menciptkanan (C6 kategori planing), sehingga jika siswa belum terlatih untuk keterampilan ini, maka sulit baginya untuk dapat melakukannya. Dari hasil analisis proses pembelajaran pada tahap eksplorasi ditemukan bahwa scaffolding yang diberikan guru tidak merata pada seluruh kelompok, sehingga tidak semua siswa mendapatkan bantuan dari guru pada tahap-tahap ini. Dengan demikian, menurut hemat peneliti kesulitan pada TPK 4 ini diduga disebakan oleh kurangnya dan tidak meratanya scaffolding yang diberikan guru ke pada siswa. Kesulitan siswa dalam menyusun definisi operasional variabel tentu akan berdampak pada ketidakmampuan siswa dalam membuat prosedur percobaan karena definisi operasional variabel berisi tentang cara variabel-variabel diukur dan dengan apa variabel-variabel itu diukur. Kesulitan siswa pada menyusun prosedur percobaan disamping disebabkan oleh ketidakmampuan siswa dalam menyusun definisi operasional variabel, juga disebabkan karena pada tipe guided discovery prosedur percobaan telah disajikan dalam LKS (diberikan), dimana siswa hanya membaca, 
memahami dan menerapkan prosedur yang sudah disajikan, sehingga aktivitas berfikir hanya berada pada level proses kognitif menerapkan (C3, kategori executing), sedangkan menyusun prosedur percobaan merupakan aktivitas berfikir yang berada pada level proses kognitif menciptakan (C6, kategori planing). Oleh karena itu dalam pembelajaran untuk kedua TPK yang level proses kognitifnya tinggi, guru perlu pemberian scaffolding yang cukup dan merata ke pada seluruh siswa, sehingga siswa tidak mengalami kesulitan untuk menujukkan kemampuannya dalam menuntaskan kedua TPK tersebut.

Berdasarkan Tabel 9 diperoleh informasi bahwa pada tipe less structured guided discovery $93,75 \%$ siswa mencapai ketuntasan belajar dengan nilai rata-rata kelas adalah 91,74 dan gain score rata-rata 67,86, sedangkan pada tipe guided discovery $60 \%$ siswa mencapai ketuntasan belajar dengan nilai rata-rata kelas adalah 61,14 dan gain score rata-rata 38,21. Dengan demikian, pembelajaran fisika dengan menerapkan perangkat pembelajaran yang berorientasi pada pendekatan pembelajaran discovery pada kedua tipe less structured guided discovery dan tipe guided discovery terbukti dapat mengembangkan keterampilan ilmiah siswa. Dari hasil analisis jawaban para siswa yang tidak tuntas pada tes keterampilan ilmiah, terlihat ada kesamaan kesulitan, yaitu siswa belum mampu menyusun hipotesis dengan benar, kesulitan ini tentu akan berdampak kemampuan siswa pada keterampilan ilmiah yang lain, sehingga perolehan skor total mereka rendah. Oleh karena itu guru dalam kegiatan pembelajaran discovery terutama pada kegiatan eksplorasi perlu memberikan scaffolding yang cukup dan merata secara langsung, walaupun definsi-definisi dari keterampilan-keterampilan ilmiah yang mereka gunakan dalam kegiatan ini sudah tercantum dalam LKS, akan tetapi siswa memiliki hetrogenitas kemampuan dalam menelaah informasi. Pada kelas tipe guided discovery ada tiga siswa yang mengalami kesulitan dalam menyusun rumusan masalah, hal ini diduga disebabkan karena siswa belum memahami bagaimana sebuah rumusan masalah itu dirumuskan dari latar belakang masalah yang diberikan. Keterampilan merumuskan masalah memang tidak dilatihkan dalam kedua tipe pembelajaran discovery, tetapi tercantum dalam LKS (diberikan) dan dijelaskan oleh guru.

Berdasarkan hasil pengujian hipotesis, keterampilan ilmiah siswa setelah diberikan pembelajaran melalui pendekatan discovery tipe less structured guided discovery lebih baik daripada tipe guided discovery. Hasil ini sejalan dengan apa yang diungkapkan oleh Carin (1993) tentang aktivitas berfikir siswa pada masing-masing tipe. Menurut Carin (1993), pada pendekatan pembelajaran discovery tipe guided discovery, guru memberikan rumusan masalah dan prosedur percobaan/pengamatan, kemudian siswa didorong untuk menyusun sendiri hipotesis, mengidentifikasi variabel, mendefinisikan variabel secara operasional, mengumpulkan data berdasarkan prosedur yang telah diberikan guru, menganalisis data, menarik kesimpulan dan menerapkan kosep atau penyelesaian masalah di dalam situasi yang lain, sedangkan pada pendekatan penemuan tipe less structured guided discovery guru hanya mengajukan rumusan masalah tanpa memberikan prosedur percobaan/pengamatan, kemudian siswa didorong untuk menyusun hipotesis, mengidentifikasi variabel, mendefinisikan variabel secara operasional, menyusun sendiri prosedur percobaan/pengamatan, menggunakan prosedur telah disusun untuk mengumpulkan data setelah disetujui oleh guru, menganalisis data, menarik kesimpulan dan menerapkan kosep atau penyelesaian masalah di dalam situasi yang lain. Keterampilan ilmiah yang dilakukan siswa pada tipe ini lebih banyak dibandingkan pada tipe guided discovery. Keterampilan ilmiah merupakan salah satu potensi intelektual anak yang harus dikembangkan dalam pembelajaran sains. Menurut Bruner (dalam Carin, 1993: 93), potensi intelektual seseorang akan berkembang hanya jika ia menggunakan potensi tersebut, artinya semakin banyak keterampilan ilmiah yang digunakan anak dalam aktivitas belajarnya maka aktivitas berfikir yang dilakukan oleh anak juga semakin tinggi sehingga berpengaruh pada potensi intelektualnya. Dengan demikian, keterampilan ilmiah siswa setelah diberikan pembelajaran melalui pendekatan discovery tipe less structured guided discovery lebih baik daripada tipe guided discovery seperti yang ditunjukkan oleh hasil pengujian hipotesis.

\section{Tingkat Tanggung Jawab Siswa}

Berdasarkan data pada Tabel 13 diperoleh informasi bahwa persentase rata-rata tingkat tanggung jawab siswa selama kegiatan pembelajaran discovey adalah 88,44 (kategori sangat tinggi) pada tipe less structured giuded discovery dan 67,21 (kategori tinggi) pada tipe guided discovery, sedangkan gain score tingkat tanggung jawab siswa adalah 21,94 pada tipe less structured giuded discovery dan 4,81 pada tipe guided discovery. Hasil ini menggambarkan bahwa karakter tanggung jawab siswa dapat dikembangkan melalui pendekatan pembelajaran penemuan (discovery learning) pada kedua tipe guided discovery dan tipe less structured guided discovery. Pendekatan discovery adalah pendekatan yang berpusat pada siswa. Hasil temuan ini sejalan dengan apa yang dikemukakan oleh Efendy (2011) bahwa karakterkarakter positif (termasuk tanggung jawab) cenderung lebih mudah dibentuk apabila pembelajaran IPA 
menggunakan pendekatan yang berpusat pada siswa (student centered) dibandingkan berpusat pada guru (teacher centered). Senada dengan pernyataan tersebut, Mulyana (2004) menyatakan bahwa di dalam pendekatan pembelajaran yang melibatkan peserta didik sepenuhnya pada suatu aktivitas belajar, peserta didik didorong untuk melakukan refleksi diri, bereaksi, menetukan akibat tindakan, dan membuat keputusan yang relervan dengan situasi belajar. Pembelajaran penemuan (discovery) merupakan suatu pembelajaran yang berpusat pada siswa, sehingga melalui pembelajaran penemuan, karakterkarakter positif, dalam hal ini tingkat tanggung jawab siswa dapat dikembangkan dalam pembelajaran. Carin (1993) menyatakan bahwa di dalam pembelajaran penemuan para siswa dididik untuk menjadi lebih mandiri, mengarahkan diri mereka sendiri dan bertanggung jawab terhadap belajar mereka sendiri.

Berdasarkan hasil pengujian hipotesis, tingkat tanggung jawab siswa dalam kegiatan pembelajaran melalui pendekatan discovery tipe less structured guided discovery lebih baik daripada tipe guided discovery. Hasil ini sejalan dengan pernyataan Carin (1993). Menurut Carin (1993), pada pendekatan pembelajaran discovery tipe guided discovery, guru memberikan rumusan masalah dan prosedur penyelesaian masalah, kemudian siswa diberi porsi tanggung jawab untuk menyelesaikan permasalahan tersebut melalui kegiatan pengumpulan data, analisis data hingga merumuskan kesimpulan atau solusi. Sedangkan pada pendekatan pembelajaran discovery tipe less structured guided discovery guru hanya mengajukan rumusan masalah tanpa memberikan metode atau prosedur penyelesaian masalah, kemudian siswa diberikan porsi tanggung jawab untuk merumuskan sendiri metode penyelesaian masalah dan menggunakan metode tersebut untuk menyelesaikan permasalahan melalui kegiatan pengumpulan data, analisis data hingga perumusan kesimpulan atau solusi. Porsi tanggung jawab yang diberikan kepada siswa pada tipe less structured guided discovery lebih besar dibandingkan pada tipe guided discovery. Semakin besar porsi tanggung jawab anak yang diberikan dalam kegiatan pembelajaran, maka semakin besar kesempatan anak untuk melakukan proses internalisasi nilai-nilai tanggung jawab ke dalam dirinya, sehingga akan berpengaruh pada tingkat tanggung jawab yang akan dimiliki oleh anak. Dengan demikian, tingkat tanggung jawab siswa di dalam kegiatan pembelajaran melalui pendekatan discovery tipe less structured guided discovery lebih baik daripada tipe guided discovery sebagaimana yang ditunjukkan oleh hasil pengujian hipotesis.

Tingkat tanggung jawab siswa diukur berdasarkan diskripsi operasional dari ciri-ciri tanggung jawab pada The Six Pillar of Character, yaitu: melakukan apa yang harus dilakukan, gigih, selalu melakukan yang terbaik, menerapkan kendali diri, disiplin, berpikir sebelum bertindak, dan bertanggung jawab terhadap pilihannya. Berdasarkan data pada Tabel 14 terlihat bahwa persentase ketercapaian setiap ciri tingkat tanggung jawab dalam kegiatan pembelajaran penemuan pada tipe less structured guided discovery sangat tinggi. Pada tipe guided discovery persentase ketercapaian setiap ciri tingkat tanggung jawab berkategori sangat tinggi dan tinggi, kecuali pada ciri melakukan yang terbaik dan menerapkan kendali diri, ketercapaiannya memiliki kategori rendah, hal ini diduga karena selama ini pembelajaran di kelas berpusat pada guru, dimana lingkungan belajarnya begitu ketat, sehingga siswa kurang memiliki inisiatif untuk melakukan sesuatu tanpa perintah. Untuk pengendalian diri yang lemah diduga disebabkan karena siswa belum terbiasa dengan lingkungan belajar yang bebas terbimbing, siswa belum terbiasa diberikan tanggung jawab untuk mengatur kegiatan belajarnya sendiri, sehingga siswa pada tahaptahap implementasi awal ini belum memahami kebebasan yang diberikan sebagai kebebasan akdemik, dimana mereka bebas untuk bereksplorasi, bukan kebebasan untuk melakukan aktivitas di luar aktivitas pembelajaran, sehingga mereka belum memiliki pengendalian diri yang baik. Jika pembelajaran penemuan yang berbasis pendidikan karakter ini terus diimplementasikan dalam pembelajaran fisika, maka proses internalisasi nilai-nilai tanggung jawab ini dapat berlangsung pada diri siswa dengan baik sehingga akan mengembangkan karakter tanggung jawab pada diri mereka. Sarkin (1998: 142) mengungkapkan bahwa dalam pengajaran di mana para murid aktif berbuat dan berpendapat, karakter pribadi murid akan terungkap. Semakin banyak murid melakukan aktivitas, akan semakin kelihatan watak kepribadiannya. Dengan demikian, semakin terbuka pula kesempatan bagi guru untuk membantu murid mengembangkan kepribadiannya. Melalui interaksi dengan guru dan sesama murid yang terus menerus dijaga, sikap dan perilaku para murid secara bertahap akan berkembang ke arah yang lebih baik.

\section{KESIMPULAN DAN SARAN \\ Kesimpulan}

Berdasarkan hasil penelitian di atas, dapat ditarik beberapa kesimpulan, yaitu:

1 Keterlaksanaan pembelajaran fisika yang menggunakan perangkat pembelajaran berorientasi pada pendekatan discovery adalah 98,08 \% pada kedua tipe guided discovery dan tipe less structured guided discovery.

2 Aktivitas siswa selama penerapan perangkat pembelajaran fisika yang berorientasi pada 
pendekatan discovery menggambarkan aktivitas siswa yang sesuai dengan tahap-tahap pembelajaran discovery baik pada tipe guided discovery maupun pada tipe less strucured guided discovery

3 Penerapan perangkat pembelajaran yang berorientasi pada pendekatan pembelajaran discovery pada kedua tipe less structured guided discovery dan tipe guided discovery telah terbukti dapat mengembangkan kemampuan akademik dan karakter tanggung jawab siswa dalam pembelajaran fisika.

4 Kemampuan kognitif siswa setelah diberikan pembelajaran melalui pendekatan discovery tipe less structured guided discovery lebih baik daripada tipe guided discovery

5 Keterampilan ilmiah siswa setelah diberikan pembelajaran melalui pendekatan discovery tipe less structured guided discovery lebih baik daripada tipe guided discovery

6 Tingkat tanggung jawab siswa dalam kegiatan pembelajaran melalui pendekatan discovery tipe less structured guided discovery lebih tinggi daripada tipe guided discovery.

\section{Saran}

Berdasarkan penelitian yang telah dilakukan dan hasil yang didapat, disarankan beberapa hal sebagai berikut.

1. Tahap-tahap pembelajaran discovery belum dapat dilaksanakan $100 \%$. Oleh karena itu dalam penelitian-penelitian lebih lanjut kuantitas dan kualitas pelatihan guru mitra dalam menerapkan perangkat pembelajaran yang berorintasi pada pendekatan discovery perlu diperhatikan.

2. Dalam tahap eksplorasi, siswa mengalami kesulitan pada tahap menyusun definisi operasional variabel, sehingga perlu bagi guru untuk memberikan scaffolding yang cukup dan merata pada seluruh siswa.

3. Salah satu kelemahan penelitian ini adalah pengamatan keterlaksanaan pembelajaran dan tingkat tanggung jawab siswa dilakukan oleh hanya satu orang pada masing-masing tipe, sehingga penilaian tingkat tanggung jawab menjadi kurang teliti. Oleh karena pada penelitian berikutnya itu setiap komponen pengamatan (keterlaksanaan pembelajaran, aktivitas siswa dan tingkat tanggung jawab siswa) diamati oleh masing-masing satu pengamat.

\section{DAFTAR PUSTAKA}

Abruscato,J. 1992. Teaching Children Science. A Discovery Approach. $3^{r d}$. Needham Heights. MA: Allyn and Bacon.
Akinbobola, A.O. dan Afolabi, F. 2010. "Constructivist Practices Through Guided Discovery Approach: The Effect on Student's Cognitive Achievements in Nigerian Senior Secondary School Physics". Eurasian J. Phys. Chem. Educ. Vol. 2, No. 1, pp. $16-25$.

Anderson, L.D. dan Krathwohl, D.R. 2001. A Taxonomy for Learning, Teaching, and Assesing. Newyork: Addison Wesley Longman, Inc.

Borich, G.D. 1994. Observation Skills for Effective Teaching. New York: Macmillan Publishing Company.

Carin, A.A. 1993. Teaching Science Through Discovery. New York: Macmillan Publishing Company.

Castronova, J.A. Tanpa tahun. Discovery Learning for the 21st Century: What is it and how does it compare to traditional learning in effectiveness in the 21st Century?. Diakses pada tanggal 20 Oktober 2010 melalui http://chiron.valdosta.edu/are/Litreviews/vol1no1/ca stronova_litr.pdf.

Collete, A.T dan Chiapetta, E.L. 1994. Science Instruction in the Middle and Secondary Schools. New York: Macmillan Publishing Company.

Depdiknas. 2003. UU RI No. 20 Tahun 2003 tentang Sistem Pendidikan nasional.

Depdiknas. 2005. Rencana Depatremen Pendidikan Nasional Tahun 2005-2009. Jakakarta: Depdiknas.

Depdiknas. 2007. Naskah Akademik. Kajian Kebijakan Kurikulum Mata Pelajaran IPA. Jakakarta: Depdiknas.

Efendy. 2011. "Aplikasi Pembelajaran IPA dalam Pembentukan Karakter Siswa". Makalah disajikan pada Seminar Nasional Sains 2011, Surabaya.

El Mubarok, Z. 2008. Membumikan Pendidikan Nilai. Bandung: Alfabeta.

Enger, SK. Dan Yager, RE. 2000. Assessing Student Understanding in Science. California: Corwin Press, Inc.

Gay, LR. 1987. Educational Research. Competencies for analysis and Application. Columbus: Merril Publishing Company.

Gronlund, N.E. 2003. Assesment of Student Achievement $7^{\text {th }} \mathrm{ed}$. United State of America: Pearson Education, Inc.

Howe, A.C. dan Jones, L. 1993. Engaging Children in Science. New York: Macmillan Publishing Company.

Ibrahim, Muslimin. 2008. Model Pembelajaran IPA Inovatif melalui Pemaknaan. Surabaya: Universitas Negeri Surabaya. 
Josephson Intitute. Tanpa Tahun. The Six Pillar of Character. Diakses pada tanggal 10 November 2010 melalui http://charactercount.org/Six.Pillar.html.

Koesuma A, D. A.2007. Pendidikan Karakter. Jakarta: GRASINDO.

Khaeruddin. 2006. "Rencana Pelaksanaan Pembelajaran". SMK Negeri 2 Sumbawa Besar.

Lavine, R.A. 2005. "Guided Discovery Learning with Videotaped Case Presentation in Neurobiology". JIAMSE. Vol. 15, pp. $4-7$.

Martin, R.E. Wagner, K. dan Gerlovich, J. 1994. Teaching Science for all Children. Boston: Allyn and Bacon.

Mayer, R.E. 2004. "Should There Be a Three-Strikes Rule Against Pure Discovery Learning?". American Psychologist. Vol. 59, No. 1, pp. 14 - 19.

Mulyana, R. 2004. Mengartikulasikan Pendidikan Nilai. Bandung: Alfabeta.

National Research Council.2000. Inquiry and National Science Education Standards. Washington, D.C. : National Academy Press.

Nur, M. Rahayu, YS. Wasis. Isna. dan Subekti, H. 2010. Pengembangan Perangkat Pembelajaran untuk Memberi Kemudahan Guru Mengajar dan Siswa Belajar IPA dan Keterampilan Berfikir. Laporan Penelitian Hibah Kompetensi. Universitas Negeri Surabaya.

Prince, M.J dan Felder, R.M. "Inductive Teaching and Learning Methods: Defenition, Comparison, and Research Bases". J. Engr. Education. Vol. 95, No. 2, pp. $123-138$.

Rahmi, 2009. "Rencana Pelaksanaan Pembelajaran". SMK Negeri 2 Sumbawa Besar.

Rohandi. 1998 "Memberdayakan Anak Melalui Pendidikan sains". Dalam Pendidikan Sains yang Humanistis. Yogyakarta: Kanisius.
Rustaman, N.Y. Tanpa tahun Kemampuan Dasar Bekerja Ilmiah dalam Pendidikan sains dan Assesmennya. diakses tanggal 1 Oktober 2010 melalui

http://file.upi.edu/Direktori/SPS/PRODI.PENDIDI KAN\%20IPA/195012311979032\%20\%20NURYANI\%20RUSTAMAN/KDBI_dalam/K DBIdalam DIKSainsFINAL.pdf.

Sarkin. 1998 "Humaniora dalam Pendidikan Sains". Dalam Pendidikan Sains yang Humanistis. Yogyakarta: Kanisius.

Sumaji. 1998. "Dimensi Pendidikan IPA dan Pengembangan sebagai Disiplin Ilmu. Dalam Pendidikan Sains yang Humanistis. Yogyakarta: Kanisius.

Thiagarajan, S. D.S, Semmel dan M.I, Semmel. 1974. Instructional Development for Training Centre of Exceptional Children. Minepolish: Indiana University.

Wadsworth, BJ. 1984. Piaget's Theory of Cognitive and Affective Development. USA: Longman Inc.

William, T Russel dan Ratna Megawangi. Tanpa tahun. Kecerdasan Plus Karakter. Diakses melalui http://ihf.org.tripod.com/pustaka/kecerdasan pluskarakter.htm. 